\title{
The effect of resistant starch on colon function in humans
}

\author{
BY J. TOMLIN AND N. W. READ \\ Sub-department of Human Gastrointestinal Physiology and Nutrition, Floor K, Royal Hallamshire \\ Hospital, Glossop Road, Sheffield SIO 2JF
}

(Received 23 November 1989 - Accepted 16 May 1990)

\begin{abstract}
Starch that is resistant to human amylases forms during the cooking and subsequent cooling of some foods, and may therefore be a substrate for the bacterial flora of the colon. It is thus possible that resistant starch (RS) will affect colon function in a similar manner to non-starch polysaccharides. To test this theory, a group of eight volunteers took two diet supplements for 1 week each in a random order with a 1 week separation. One supplement comprised mainly $350 \mathrm{~g}$ Cornflakes/d and the other $380 \mathrm{~g}$ Rice Krispies/d, providing 10.33 and $0.86 \mathrm{~g} \mathrm{RS/d}$ respectively. The amounts of amylase-digestible starch, nonstarch polysaccharides, total carbohydrate, energy, protein and fat were balanced between the two periods by giving small amounts of Casilan, wheat bran, butter and boiled sweets. The volunteers made faecal collections during day 3 to day 7 of each period. Whole-gut transit time was calculated using the continuous method. Stool consistency and ease of defaecation were assessed by the volunteers. All episodes of flatulence noticed were recorded in a diary, along with food intake. Serial breath hydrogen measurements were made at $15 \mathrm{~min}$ intervals for $8 \mathrm{~h}$ on day 1 of each supplement. Questionnaires regarding colon function were completed at the end of each dietary period. There were no significant differences in the stool mass, frequency or consistency, ease of defaecations, transit time or flatulence experienced during the two supplements $(P>0.05)$. Significantly more $\mathrm{H}_{2}$ (area under curve) was produced while eating Cornflakes than Rice Krispies $(P<0.05)$. The difference of $9.47 \mathrm{~g} \mathrm{RS} / \mathrm{d}$ between the two diets was over three times the calculated normal daily RS intake of $2.76 \mathrm{~g} / \mathrm{d}$. As the only significant difference observed was in the breath $\mathrm{H}_{2}$ excretion on day 1 , we suggest that either $\mathrm{RS}$ is rapidly and completely fermented to end-products including $\mathrm{H}_{2}$ gas, which is subsequently excreted via the lungs and has little influence on colon function, or that bacterial adaptation removed any observable effect on faecal mass and transit time by day 3 .
\end{abstract}

Starch: Hydrogen: Faeces: Whole-gut transit time: Colon

Until recently starch was thought to be completely hydrolysed in, and absorbed from, the small intestine of man because of the presence of excess quantities of salivary and pancreatic $\alpha$-amylase (EC 3.2.1.1). However, a number of foods contain some starch that resists dispersion in water and hydrolysis with pancreatic amylase in vitro for various reasons (Englyst et al. 1987). Retrograded amylose is one type of resistant starch (RS) that forms when foods that have been baked or boiled are subsequently cooled $\left(\mathrm{RS}_{3}\right)$; some of the dispersed starch is thought to recrystallize and strong intermolecular hydrogen bonds are formed. Other forms of starch that resist digestion include the raw starch present in bananas, starch in unmilled grains and seeds, and retrograded amylopectin.

Starch that resists breakdown in the small intestine will pass into the large intestine where it may act in a similar manner to the unabsorbed non-starch polysaccharides of dietary fibre. Some non-starch polysaccharides reduce whole-gut transit time and increase stool output, and there are various mechanisms proposed to explain these effects. One of these proposals is that the carbohydrates act as substrate to the bacteria, stimulating bacterial growth and increasing bacterial cell mass (Stephen \& Cummings, 1980) and generating fermentation end-products such as short-chain fatty acids (SCFA) and gases, which may 
affect colonic motility and secretion (Fleming et al. 1983). Human colonic bacteria are capable of fermenting RS in in vitro incubations, resulting in an increase in the bacterial cell mass and production of SCFA (Englyst \& MacFarlane, 1986). H. N. Englyst (personal communication) has suggested that RS in its various forms may contribute more substrate to the colonic bacteria than other polysaccharides. RS may, therefore, be very important in maintaining normal colon function, but there are no published values on the amount in the 'normal diet'. The effect of ingestion of RS on stool output and gas production in humans has never been studied before. Published investigations into the in vivo effects of RS are limited to a single study on the rat (Faulks et al. 1989). This showed that addition of between 1.32 and $1.54 \mathrm{~g} \mathrm{RS} / \mathrm{d}$ to the diet caused a slight increase in faecal output over $30 \mathrm{~d}$.

The aims of the present experiment were to investigate whether $\mathrm{RS}_{3}$ can influence colonic function in humans by monitoring whole-gut transit time, stool mass, frequency and consistency, flatus production and the ease of defaecation, and to test whether $\mathrm{RS}_{3}$ affects breath levels of the fermentation end-product, $\mathrm{H}_{2}$, as this may give an indication of the amount of substrate being fermented in the colon (Flourie et al. 1986).

Studies were carried out in normal volunteers who were asked to supplement their normal diets, with commercial breakfast cereals containing different amounts of $\mathrm{RS}_{3}$ during two 1 -week periods.

\section{METHODS \\ Volunteers}

We recruited eight healthy male volunteers who consumed a standard Western diet and had no history of gastrointestinal illness or bowel disturbance. Each gave his written informed consent, and the study was approved by the Ethical Committee of the Sheffield Area Health Authority.

\section{Protocol}

The study lasted $21 \mathrm{~d}$ in total, and was made up of two $7 \mathrm{~d}$ study periods, separated by 1 week. Dietary supplements were administered during the two study periods in a random order.

During one of the 1-week study periods the subjects' diets were supplemented with $350 \mathrm{~g}$ Kellogg's Cornflakes/d (providing $10.33 \mathrm{~g} \mathrm{RS}_{3} / \mathrm{d}$ ). During the other period $380 \mathrm{~g}$ Kellogg's Rice Krispies/d was taken (providing $0.86 \mathrm{~g} \mathrm{RS}_{3} / \mathrm{d}$ ). These amounts of cereal are equivalent to six large bowls/d. In addition to the breakfast cereals, small amounts of bran, butter, boiled sweets and Casilan (Farley Health Products Ltd, Nottingham) were consumed to balance the nutritional composition of the two supplements. The precise amounts were calculated using published data on their composition (Paul \& Southgate, 1978). The amounts of non-starch polysaccharides, energy and fat provided by the two diets were balanced exactly, whilst the amounts of total starch, protein and total carbohydrate were balanced to within $1 \%$ of each other (Table 1 ).

The volunteers were encouraged to maintain their normal diet as far as possible but to restrict their alcohol consumption to no more than fifteen units/week and no more than four units/d ( 1 unit is equivalent to 0.5 pints beer, one glass of wine or one measure of spirits). It was accepted that the cereal supplements and accompanying milk and sugar would displace a certain amount of the normal dietary intake. The volunteers kept a diary of their food intake using approximate portion sizes, and they were encouraged to eat similar foods during the two study-weeks and to avoid foods known to affect their bowel habit. The approximate energy, starch and non-starch polysaccharide intakes were calculated from the diaries using food tables (Paul \& Southgate, 1978). 
Table 1. The composition $(g)$ of the daily dietary supplements for the two study periods calculated to provide a difference in intake of about $9.5 \mathrm{~g}$ resistant starch $(R S) / d$ for healthy adult male volunteers

\begin{tabular}{|c|c|c|c|c|c|c|c|}
\hline & RS & Starch & NSP & $\begin{array}{c}\text { Energy } \\
(\mathrm{MJ})\end{array}$ & Protein & Fat & $\mathrm{CHO}$ \\
\hline \multicolumn{8}{|l|}{ Diet $A$} \\
\hline 350 g Cornflakes* & $10 \cdot 33$ & $262 \cdot 1$ & $2 \cdot 28$ & $5 \cdot 39$ & $30 \cdot 1$ & $5 \cdot 6$ & 298 \\
\hline $33 \mathrm{~g}$ Boiled sweets & 0 & $0 \cdot 1$ & 0 & 0.45 & 0 & 0 & 28 \\
\hline $2.4 \mathrm{~g} \mathrm{Bran}$ & 0 & $0 \cdot 3$ & 0.88 & 0.02 & 0.3 & 0.1 & 6 \\
\hline $2 \cdot 3 \mathrm{~g}$ Butter & 0 & 0 & 0 & 0.07 & 0 & $1 \cdot 9$ & 0 \\
\hline Total & $10 \cdot 33$ & $262 \cdot 5$ & $3 \cdot 16$ & 5.93 & $30 \cdot 4$ & $7 \cdot 6$ & 332 \\
\hline \multicolumn{8}{|l|}{ Diet $B$} \\
\hline 380 g Rice Krispies* & $0 \cdot 86$ & $262 \cdot 1$ & $3 \cdot 16$ & $5 \cdot 79$ & $22 \cdot 0$ & $7 \cdot 5$ & 327 \\
\hline $9 \mathrm{~g}$ Casilan $\dagger$ & 0 & 0 & 0 & $0 \cdot 14$ & $8 \cdot 1$ & $0 \cdot 1$ & 0 \\
\hline Total & 0.86 & $262 \cdot 1$ & $3 \cdot 16$ & $5 \cdot 93$ & $30 \cdot 1$ & $7 \cdot 6$ & 327 \\
\hline Difference $(\mathrm{A}-\mathrm{B})$ & $9 \cdot 47$ & 0.4 & 0 & 0 & $0 \cdot 3$ & 0 & 5 \\
\hline
\end{tabular}

During the entire $21 \mathrm{~d}$ the volunteers ingested fifteen small plastic radio-opaque markers at about the same time each day noting the exact time of ingestion in a diary.

During the last $5 \mathrm{~d}$ of both study periods the volunteers collected all stools into individual plastic bags, labelled with the time and date of defaecation. The stools were then weighed to yield the stool mass, and $\mathrm{X}$-rayed to visualize the radio-opaque markers. The whole-gut transit time was calculated using the continuous method of Cummings et al. (1976); the number of markers excreted in each stool was fitted into an equation, along with the times of marker ingestion, to give the mean time taken for the markers to pass from mouth to anus each day.

The volunteers also noted in the diary the time each stool was passed and this allowed calculation of the stool frequency. They noted the ease of each defaecation on a visual analogue scale with the 0 and 100 points labelled 'no effort' and 'much straining'. They assessed the consistency of the resultant faeces on a scale from 1 to 8 by comparison with a set of standard descriptions and photographs, based on a linear scale of stool consistency devised by Davies et al. (1986). During the two study periods they noted all episodes of flatus passage per rectum in the diary.

The volunteers spent $8 \mathrm{~h}$ of the first day of each period in the laboratory to allow repeated measurements of breath $\mathrm{H}_{2}$ concentration to be made. End expiratory breath samples were taken at 15 min intervals using a modified Haldane-Priestley tube, and the $\mathrm{H}_{2}$ concentration was measured using a breath $\mathrm{H}_{2}$ monitor (GMI, Renfrew, Scotland). The area under the $\mathrm{H}_{2}$ curve was calculated (with no base-line correction), and this was used to give an indication of the amount of substrate fermented. The amounts and timings of the cereals and other food and drink consumed during this sampling period were repeated exactly on both occasions.

\section{Statistics}

Paired results from the two periods were compared using Wilcoxon's matched pairs rank sum test. 
Table 2. Bowel function measurements during intake of two supplements providing a difference in intake of about $9.5 \mathrm{~g}$ resistant starch/d by healthy adult male volunteers

(Mean values for eight subjects)

\begin{tabular}{|c|c|c|}
\hline Supplement ... & Cornflakes $\$$ & Rice Krispies§ \\
\hline Faecal output $(\mathrm{kg} / 5 \mathrm{~d})$ & $0 \cdot 89$ & 0.98 \\
\hline Median whole-gut transit time (h) & $43 \cdot 4$ & $39 \cdot 5$ \\
\hline Stool frequency (no./5 d) & $5 \cdot 0$ & $5 \cdot 8$ \\
\hline Total breath hydrogen (ppm. $\min / 8 \mathrm{~h}$ ) & $12072^{*}$ & 7529 \\
\hline Total flatulent episodes (no./week) & 35 & 27 \\
\hline Mean consistency $\dagger$ & $5 \cdot 0$ & $5 \cdot 0$ \\
\hline Mean ease of defaecation $\neq$ & 28 & 30 \\
\hline
\end{tabular}

* Mean value was significantly different from that for Rice Krispies: $P<0.05$.

+ Rated on scale from 1 (liquid) to 8 (hard pellets).

\$ Rated on scale from 0 (no effort) to 100 (much straining).

$\S$ Kelloggs.

\section{RESULTS}

\section{Faecal output}

There was no significant difference between the total mass of faeces collected during the last $5 \mathrm{~d}$ of the two study periods $(P>0.05$; Table 2$)$.

There were also no significant differences in the stool frequency, the mean consistency of the faeces or in the ease of defaecations recorded by the volunteers in the diaries $(P>0.05$; Table 2).

The questionnaires revealed that both supplements seemed to reduce the amount of faeces produced, to make the stools firmer, reduce the frequency of defaecation and to make defaecation more difficult compared with the normal bowel habit. There were no significant differences in the subjective assessments between the two study periods.

\section{Transit time}

Whole-gut transit times were not significantly different between the two periods $(P>0 \cdot 05$; Table 2).

\section{Flatulence}

There were no significant differences in the number of flatulent episodes recorded $(P>$ 0.05 ), although when the results of all volunteers for each period were added together Cornflakes produced sixty-three more episodes than Rice Krispies. Volunteers reported that both supplements reduced episodes of flatulence compared with their normal diets.

\section{Breath $\mathrm{H}_{2}$}

Breath $\mathrm{H}_{2}$ excretion, measured as the area under the breath $\mathrm{H}_{2}$ curve, was significantly higher on Cornflakes than on Rice Krispies over the $8 \mathrm{~h}$ measurement period $(P<0.05$; Table 2). Although there was considerable inter-individual variation in breath $\mathrm{H}_{2}$ levels as shown by the large standard deviations (Fig. 1), the levels were consistently higher during Cornflake ingestion.

\section{Food intake}

There were considerable differences in the background dietary intake of individuals as shown by the large ranges (Table 3 ). In paired analysis, however, there were no significant differences between the two periods $(P<0.05$; Table 3$)$. 


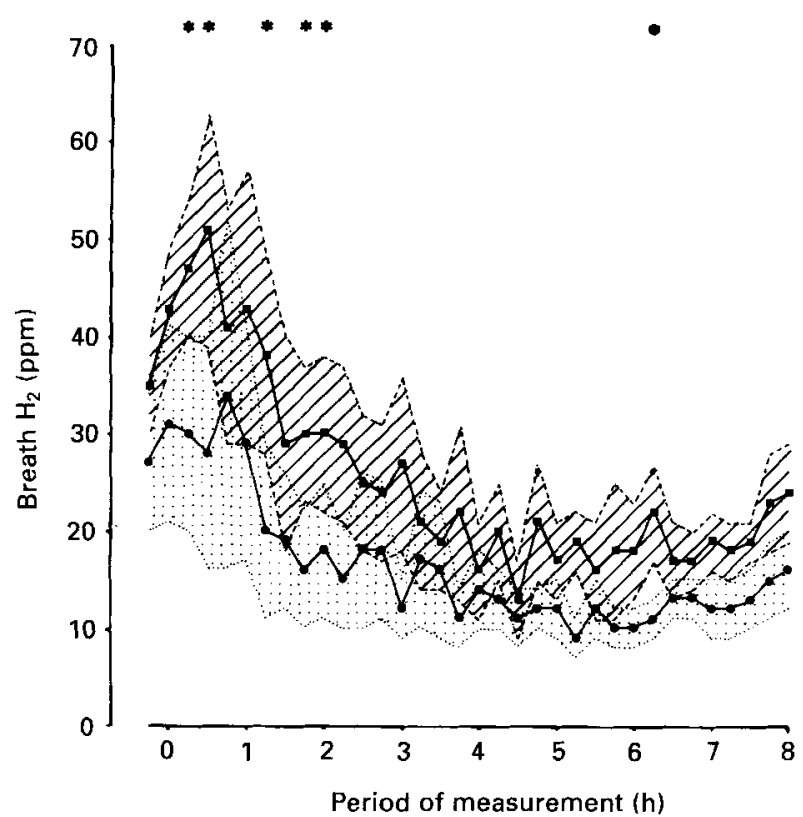

Fig. 1. Mean breath hydrogen values during $8 \mathrm{~h}$ on the first day of dietary supplementation with $350 \mathrm{~g}$ Cornflakes (Kelloggs)/d (, with range of SE shown by cross hatching) and $380 \mathrm{~g}$ Rice Krispies (Kelloggs)/d (O, with range of SE shown by dappling). * Mean values were significantly different (two-tailed Student's $t$ test), $P<0.05$.

Table 3. Energy, non-starch polysaccharide and total starch intake from the background diet during intake of two supplements providing a difference of about $9.5 \mathrm{~g}$ resistant starch $/ d$, and the total intake including supplement for healthy adult male volunteers

(Mean values with their standard errors)

\begin{tabular}{|c|c|c|c|c|}
\hline \multirow[t]{2}{*}{ Supplement ... } & \multicolumn{2}{|c|}{ Cornflakes ${ }^{\dagger}$} & \multicolumn{2}{|c|}{ Rice Krispies $\dagger$} \\
\hline & Background & +Supplement & Background & + Supplement \\
\hline \multicolumn{5}{|l|}{ Energy $(\mathrm{MJ})$} \\
\hline Mean & $5 \cdot 02$ & $10 \cdot 95$ & 5.04 & $10 \cdot 97$ \\
\hline $\mathrm{SE}$ & $1 \cdot 02$ & - & $1 \cdot 14$ & - \\
\hline Range & $1 \cdot 82-9 \cdot 75$ & $7 \cdot 75-15 \cdot 68$ & $1 \cdot 82-10 \cdot 61$ & $7 \cdot 75-16.54$ \\
\hline \multicolumn{5}{|c|}{ Non-starch polysaccharide (g) } \\
\hline Mean & $14 \cdot 8$ & $18 \cdot 0$ & $14 \cdot 9$ & $18 \cdot 1$ \\
\hline SF & $3 \cdot 1$ & - & $2 \cdot 7$ & - \\
\hline Range & $4 \cdot 4-27 \cdot 1$ & $7 \cdot 6-30 \cdot 3$ & $4 \cdot 425 \cdot 1$ & $7 \cdot 6 \cdot-28 \cdot 3$ \\
\hline \multicolumn{5}{|l|}{ Starch (g) } \\
\hline Mean & $81 \cdot 2$ & $343 \cdot 7$ & $80 \cdot 7$ & $342 \cdot 8$ \\
\hline $\mathrm{SE}$ & $13 \cdot 9$ & - & $16 \cdot 5$ & - \\
\hline Range & $31 \cdot 0-132 \cdot 0$ & $293 \cdot 5-394 \cdot 5$ & $31 \cdot 0-156 \cdot 6$ & $293 \cdot 1-418 \cdot 7$ \\
\hline
\end{tabular}


The order in which the supplements were given had no effect as there was no significant difference between any of the results when the first and second periods were compared ( $P$ $>0.05)$.

\section{DISCUSSION}

Using values for the RS content of a number of foods and food ingredients, established from the literature (Englyst et al. 1983; Englyst \& Cummings, 1984, 1986, 1987), and the average weekly consumption of these foods (and foods prepared from the food ingredients) by the general UK population (Annual Report of the Food Survey Committee, 1985), we calculated the normal intake of RS in the UK to be about $2.76 \mathrm{~g} / \mathrm{d}$. Therefore, the Cornflake supplement should have provided over three times the normal amount of RS in the UK diet to the colonic bacteria. However, our results suggest that the difference in the quantity of RS supplied by the two supplements $(9.47 \mathrm{~g} / \mathrm{d})$ is not sufficient to cause any change in faecal output, stool frequency and consistency or whole-gut transit time.

Of course it is possible that RS is less resistant to amylase digestion in vivo than in vitro (Dreher et al. 1984), and so less than $10.33 \mathrm{~g} / \mathrm{d}$ was being supplied by the Cornflakes, or that the background 'dietary fibre' intake of up to $27 \cdot 1 \mathrm{~g} / \mathrm{d}$, and dietary starch intake of up to $156.6 \mathrm{~g} / \mathrm{d}$ may have masked the effect of a relatively small quantity of $\mathrm{RS}$. Nevertheless, the significant difference in excretion of breath $\mathrm{H}_{2}$ on the first day of diet supplementation suggests that a larger amount of fermentable residue was reaching the colonic bacteria from the Cornflakes. The amount of flatulence experienced was also higher during the Cornflake period, although this did not reach statistical significance.

It is possible that the RS in Cornflakes is primarily being converted to gas which is subsequently lost from the colon, rather than into SCFA or other metabolites which could be further used by the bacteria for cell growth. It has been postulated that if a readily fermentable substrate is degraded too quickly then bacterial cell yields may not increase because energetic uncoupling occurs; energy is provided at a rate which exceeds the capacity of the bacterial community to use it for biosynthesis (Hespell \& Bryant, 1979). Previous studies have observed that the complex polysaccharides that are extensively fermented to gaseous end-products are usually those that are most readily degradable by the bacteria, and are also those that are not effective at increasing stool mass (Fleming et al. 1983; Tomlin et al. 1988). Flourie et al. (1986) found that the colonic bacteria could almost completely metabolize a colonic infusion of $50 \mathrm{~g}$ raw wheat starch causing no change in faecal mass, but producing a substantial increase in breath $\mathrm{H}_{2}$.

Since $\mathrm{H}_{2}$ measurements were carried out on day 1 and the stool measurements on days 3-7, another possibility is that the bacteria could have adapted to the RS so that any initial change in fermentation characteristics would not necessarily be manifested in a change in stool output by day 3 . The results of the rat study showed that the digestion of RS in the colon was almost complete at $97.5 \%$ after an adaptation period of only $1 \mathrm{~d}$ (Faulks et al. 1989).

In conclusion, in spite of the possible adaptation mechanisms involved, our findings do not support the view that an increase in intake of RS is likely to cause important changes in colon function.

\section{REFERENCES}

Annual Report of the National Food Survey Committee (1985). Household Food Consumption and Expenditure 1983. London: H.M. Stationery Office.

Cummings, J. H., Jenkins, D. J. A. \& Wiggins, H. S. (1976). Measurement of the mean transit time of dietary residue through the human gut. Gut $17,210-218$.

Davies, G. J., Crowder, M., Reid, B. \& Dickerson, J. W. T. (1986). Bowel function measurements of individuals with different eating patterns. Gut 27, 164-169. 
Dreher, M. L., Dreher, C. J. \& Berry, J. W. (1984). Starch digestibility of foods: a nutritional perspective. CRC Critical Reviews in Food Science and Nutrition 20, 47-71.

Englyst, H. N., Anderson, V. \& Cummings, J. H. (1983). Starch and NSP in some cereal foods. Journal of the Science of Food and Agriculture 34, 1434-1440.

Englyst, H. N. \& Cummings, J. H. (1984). Simplified method for the measurement of total NSP by GLC of constituent sugars as alditol acetates. Analyst 109, 937-942.

Englyst, H. N. \& Cummings, J. H. (1986). Digestion of carbohydrates of banana in the human sntall intestine. American Journal of Clinical Nutrition 44, 42-50.

Englyst, H. N. \& Cummings, J. H. (1987). Digestion of polysaccharides of potato in the small intestine of man. American Journal of Clinical Nutrition 45, 423-431.

Englyst, H. N. \& MacFarlane, G. T. (1986). Breakdown of resistant and readily digestible starch by human gut bacteria. Journal of the Science of Food and Agriculture 37, 699-706.

Englyst, H. N., Trowell, H., Southgate, D. A. T. \& Cummings, J. H. (1987). Dietary fibre and resistant starch. American Journal of Clinical Nutrition 46, 873-874.

Faulks, R. M., Southon, S. \& Livesey, G. (1989). Utilization of $\alpha$-amylase (EC 3.2. I . 1) resistant maize and pea (Pisum sativum) starch in the rat. British Journal of Nutrition 61, 291-300.

Fleming, S. E., Marthinsen, D. \& Kuhnlein, H. (1983). Colonic function and fermentation in men consuming high fibre diets. Journal of Nutrition 113, 2535-2544.

Flourie, B., Florent, C., Jouany, J.-P., Thivend, P., Etanchaud, F. \& Rambaud, J. C. (1986). Colonic metabolism of wheat starch in healthy humans. Gastroenterology $90,111-119$.

Hespel], R. B. \& Bryant, M. P. (1979). Efficiency of rumen microbial growth: influence of some theoretical and experimental factors on ATP. Journal of Animal Science 49, 1640-1659.

Paul, A. A. \& Southgate, D. A. T. (1978). McCance \& Widdowson's The Composition of Foods, 4th edn. London: H.M. Stationery Office.

Stephen, A. M. \& Cummings, J. H. (1980). Microbial contribution to human faecal mass. Journal of Medical Microbiology 13, 45-56.

Tomlin, J., Taylor, J. S. \& Read, N. W. (1988). The effects of mixed faecal bacteria on a selection of viscous polysaccharides in vitro. Nutrition Reports International 39, 121-135. 